\title{
Article \\ Comparitive Study of the Geomorphological Characteristics of Valley Networks between Mars and the Qaidam Basin
}

\author{
Lu Chen, Yi Xu* $*$ and Bo Li \\ State Key Laboratory of Lunar and Planetary Sciences, Macau University of Science and Technology, \\ Macau 519020, China; 1909853qse30002@student.must.edu.mo (L.C.); \\ 2009853xsd20002@student.must.edu.mo (B.L.) \\ * Correspondence: yixu@must.edu.mo
}

Citation: Chen, L.; Xu, Y.; Li, B.

Comparitive Study of the

Geomorphological Characteristics of Valley Networks between Mars and the Qaidam Basin. Remote Sens. 2021, 13, 4471. https://doi.org/10.3390/ rs13214471

Academic Editor: Louis Scuderi

Received: 7 October 2021

Accepted: 5 November 2021

Published: 7 November 2021

Publisher's Note: MDPI stays neutral with regard to jurisdictional claims in published maps and institutional affiliations.

Copyright: (c) 2021 by the authors. Licensee MDPI, Basel, Switzerland. This article is an open access article distributed under the terms and conditions of the Creative Commons Attribution (CC BY) license (https:// creativecommons.org/licenses/by/ $4.0 /)$.

\begin{abstract}
The complex valley networks that cross the Martian surface offer geomorphologic evidence of the presence of liquid water at some point in its history. However, the derivation of both temporal and hydrological dimensions of this climate phase is far from settled. Studies comparing terrestrial fluvial networks of known formation environments with those on Mars can be used as a key to unlock the past. This work represents an analogy study and comparison between the river networks in the Qaidam Basin and those on Mars. As the Martian valley networks formed in different geologic periods with characteristic and unique features, three cases from the Noachian to the Amazonian were selected to be compared with streams in the Mangya area, where the climate is extremely arid. In terms of the maturity of the dendritic river system, shape, concave index, and branching angle (BA), the valley network in the Mangya area is comparable to Naktong Vallis, dated to the Hesperian. We also calculated throughout the valley networks on Mars the parameters of the BA and the concave index, both of which are important climatic indicators. The results show that the climate on Mars became progressively more arid, starting from the Noachian up to the Amazonian.
\end{abstract}

Keywords: Qaidam Basin; valley networks; Mars; geomorphology

\section{Introduction}

The ancient fluvial systems on Mars, branching channel systems known as "valley networks", are considered one of the most compelling pieces of evidence that liquid water was once stable on Mars' surface [1-3]. However, the formative processes of how the thousand-meter-wide valley network cuts through the bedrock are unclear. Due to the uncertainty of the valley incision processes, the corresponding climatic conditions are also unclear, and the potential past habitability of Mars needs to be further assessed. The following potential causes have been considered for decades, i.e., whether networks were formed by groundwater sapping [4], precipitation-recharged groundwater sapping [5], ice melt, or fluvial runoff [6]. Different scenarios have profoundly different implications for Mars' climatic history and thus for its habitability in the distant past [7].

Valley networks are widely distributed across the Martian surface $\left(60^{\circ} \mathrm{S}-60^{\circ} \mathrm{N}\right)$, and are thought to have formed during wet periods, ranging from the end of the Noachian to that of the early Hesperian, that produced dendritic valley networks [1]. The Noachian formations account for $94 \%$ of the global valley network, while the valleys of the Hesperian and Amazonian account for $4 \%$ and $2 \%$, respectively $[8,9]$. It is observed that the latter ones have a single channel or fewer dendritic valleys. Prior work explored how the geometry of channel networks can provide insight into how they formed, and thus help constrain Mars' climatic history. For example, in a humid area, many tributaries that form the dendritic drainage have concave-up profiles, with the largest branching angle being nearly $72^{\circ}$, while the stream remains nearly straight and less dendritic, forming smaller branching angles of about $45^{\circ}$ in arid areas $[10,11]$. 
An analogue study that compares the geomorphological characteristics of valley networks on Earth and Mars is a common method used to study how the geometry of Mars' channel networks helps to constrain Mars' climatic history. Studies have compared stream morphometric parameters between rivers in the Tarim Basin and Evros Valley on Mars, e.g., concave-upward longitudinal profiles and stream fractal dimensions, supporting the hypothesis that Evros Valley represents a mature drainage system formed by precipitationdriven surface runoff. This would have occurred either in continuously warm-wet climate phases that lasted long enough in early Mars, or in regional hydrologic cycles consisting of precipitation and runoff that occasionally returned in intermittently clement climates [12]. The fluvial erosion volume and discharge on Mars [6], estimated with geometrical parameters, suggest that the erosion occurred relatively briefly during the Hesperian, but recurring episodes of erosion intervals were more likely than sustained flow [13]. The first-order formative discharges of the Martian valley networks were comparable to the terrestrial valley, $\sim 300-3000 \mathrm{~m}^{3} / \mathrm{s}$ [6], and were close to the terrestrial floods supplied by precipitation.

In this work, we choose the valleys in the Qaidam Basin on Earth, one of the highest, driest, and largest deserts, to compare with those on Mars. The Basin is a typical continental desert climate with an average temperature of $2.6^{\circ} \mathrm{C}$ [14]. The annual precipitation rate is $16-190 \mathrm{~mm}$ (from west to east), and the relative annual evaporation rate is 1974-3183 mm [15] due to strong sunlight and a dry climate. With the extremely low precipitation, low average temperature, and high evaporation rates [16], the Qaidam Basin is one of the best Martian analogue study sites in China. Many Martian-like terrains, such as aeolian dunes and yardangs, polygons, gullies, valleys, and fluvial fans, are found in the Basin. The rivers are mainly produced by snowmelt water and precipitation occurring in the mountainous region: the mountains surrounding the Basin are the birthplace of many rivers in the Basin and the main source of groundwater recharge in the Basin. In these areas, the coverage of the river network is dense, with long and widespread tributaries, with the main ones arranged in a grid pattern. The shape of the valleys in the Qaidam Basin is always less branching, and similar to that of the Hesperian to Amazonian valleys on Mars.

We extracted the valley networks on Mars based on the work of Hynek [9] and Alemanno [8], as well as those of the Qaidam Basin to compare their geomorphology parameters (e.g., drainage density, fractal dimension, stream order, branching angle, and normalized concavity index). We chose three cases, representing different geological history units, to analyze the geomorphological characteristics of valley networks and compare them with the river on Mangya. Next, two morphological parameters, the branching angle (BA) and the normalized concavity index (NCI), which have been demonstrated to be closely related to climatic aridity $[7,11]$ were considered. The BAs of the global valley networks on Mars were extracted and analyzed. The NCIs of 71 representative valley networks on Mars formed in different geologic periods were calculated and compared with those in the Mangya area. The results show that the characteristics of the valley networks in the Qaidam Basin are similar to the valley networks of the Noachian and Hesperian on Mars, which provide insight into the climate during these periods.

\section{Geologic Settings of the Qaidam Basin}

The Qaidam Basin in the northwest of China on the Tibetan Plateau, located 2800-3300 m above sea level. It is surrounded by the Altun Mountains, the Kunlun Mountains, and Qilian Mountains, and is slightly triangular with an east-west length of about $800 \mathrm{~km}$, a width of about $300 \mathrm{~km}$ from north to south, and an area of about 120,000 square kilometers (Figure 1). In the middle to late Tertiary, the subduction intensified, and the Qaidam area collapsed with the overall rapid rise of the Qinghai-Tibet Plateau, forming the structure of the Qaidam fault basin. A large and continuous Cenozoic stratum was developed in the Basin, and the tectonic uplift process as well as the regional climate evolution history of the surrounding hills are recorded in detail [14]. 


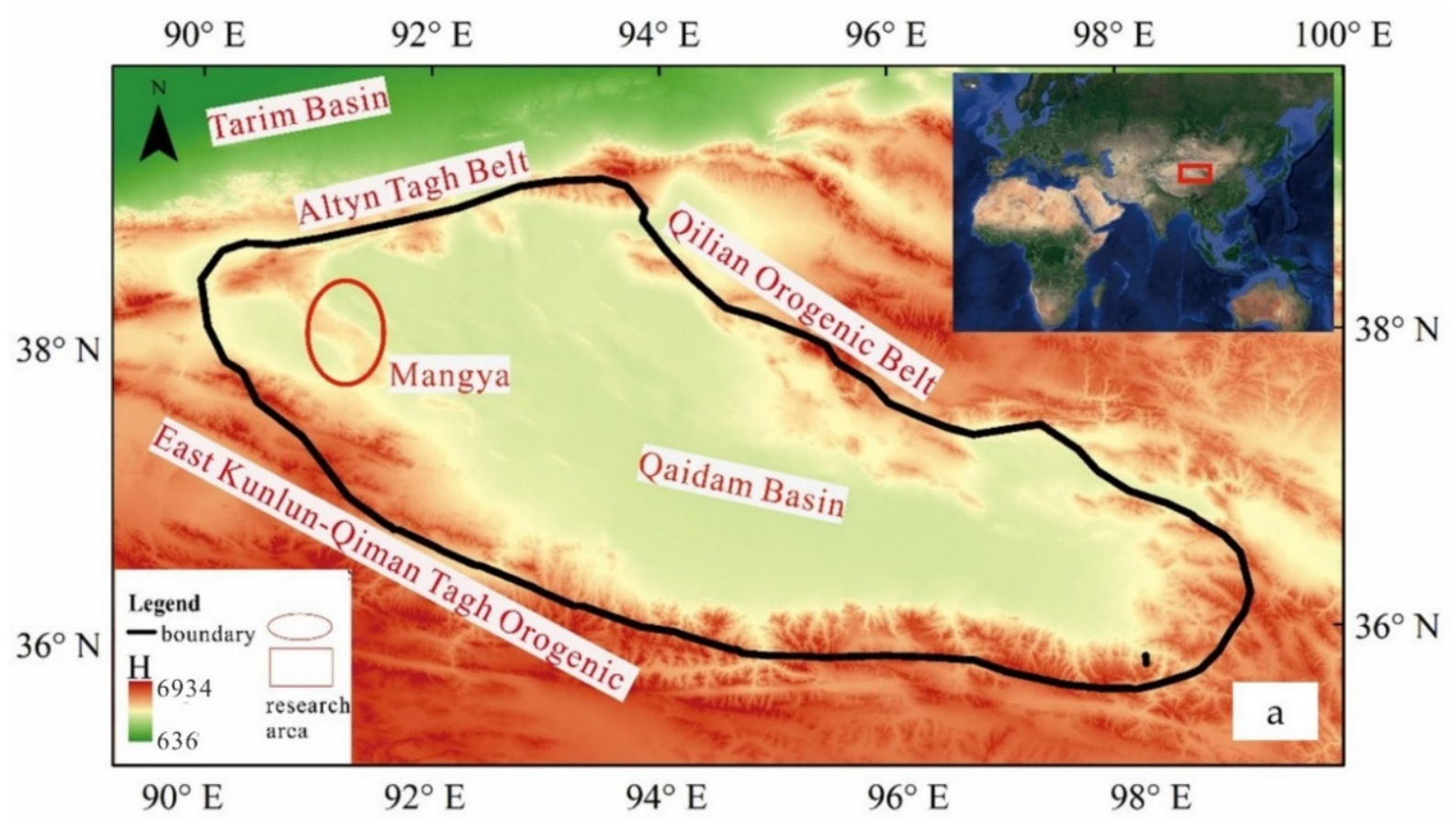

(a)

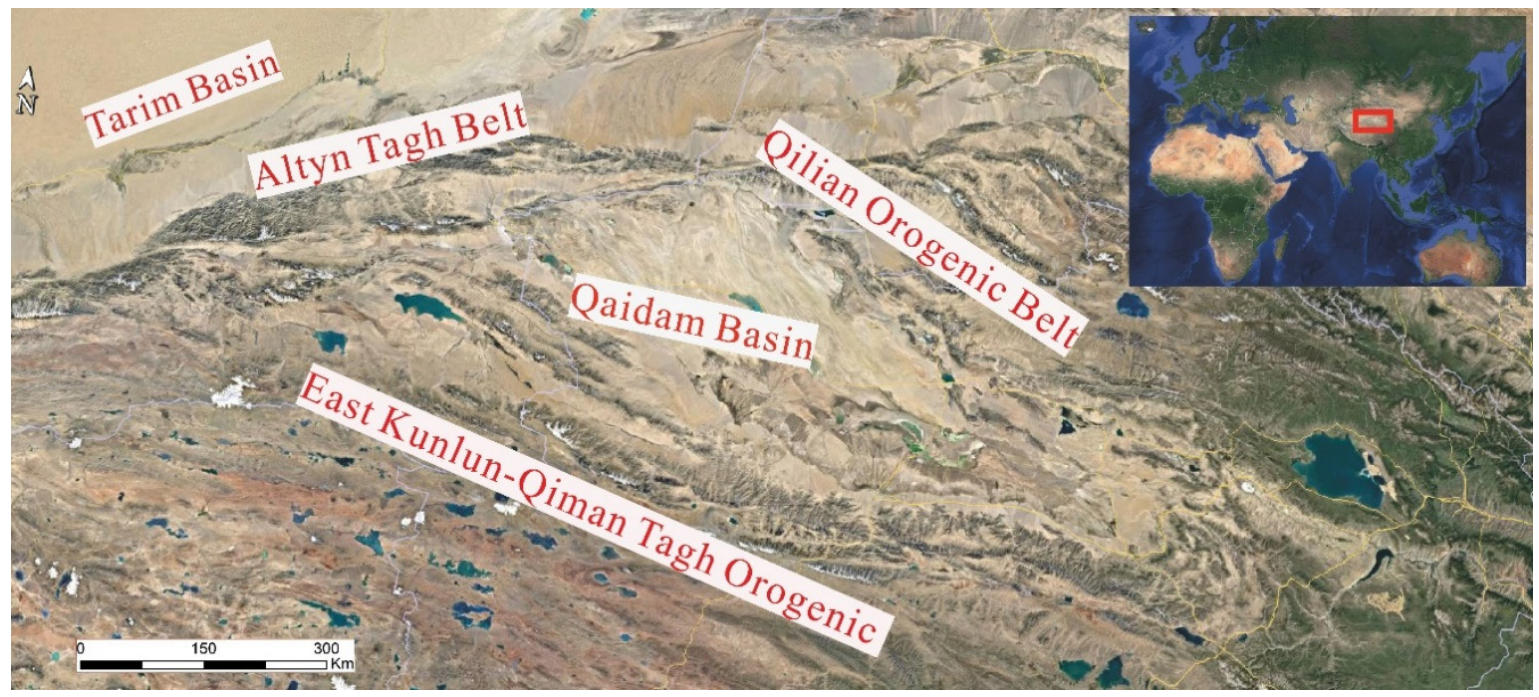

(b)

Figure 1. The elevation (a) and visible light image (b) of the Qaidam Basin. The red circle in (a) indicates the research area. The elevation data (a) are generated from the Advanced Spaceborne Thermal Emission and Reflection Radiometer Global Digital Elevation Model. Remote sensing image credit: Google Earth.

Along the uplift of the Tibetan plateau, monsoons increased the aridity in Central Asia and increased dust transport from the late Miocene [17]. The Qaidam Basin is the largest intermountain fault basin in the Tibetan Plateau's evolution in the Cenozoic, deposited with nonmarine sedimentary rocks $[18,19]$. The drilling, sedimentary, and seismic data suggest that the depocenter represented the western part of the Qaidam Basin during the Oligocene to the Quaternary. The sediment of the Mangya area was transported by the Tula trough, a paleo-river that developed along the north of the Altyn Tagh strike-slip fault and the East Kunlun thrust belt on the south [18]. Today, the climate of the Qaidam Basin is dry with low precipitation. The rivers in the Basin are developed along the surrounding mountains and the water is supplied by melted ice, groundwater, and precipitation [20]. 
The rivers developed the more complex dendritic drainage system with the melted ice and groundwater in the southeastern part of the Qaidam Basin (Table 1). The anthropogenic influence results in the unnatural evolution of the rivers. For this study, we choose the Mangya area to compare with the valley networks on Mars because of the simple supply of the river and environmental similarities, such as low precipitation and high evaporation.

Table 1. The hydrological characteristics of streams in the Qaidam Basin. Organized by Tan Yi and Zhang Jiazhen [20]. QB: Qaidam Basin.

\begin{tabular}{|c|c|c|c|c|c|}
\hline Stream & Mangya & Bayin River & Yuqia River & Geermu River & Dulan River \\
\hline Site of $Q B$ & Northwest & East & Northeast & Southeast & Southeast \\
\hline Water source & Precipitation & $\begin{array}{l}\text { Precipitation and } \\
\text { groundwater }\end{array}$ & Melted ice & Groundwater & Groundwater \\
\hline Annual precipitation (mm) & $<25$ & $35-250$ & $25-200$ & $25-300$ & $25-300$ \\
\hline Annual runoff depth (mm) & 15.1 & $0-60$ & $0-50$ & $0-100$ & $0-75$ \\
\hline Evaporation $(\mathrm{mm})$ & 1800 & $1000-1800$ & $1000-2000$ & $1000-2000$ & $1000-2000$ \\
\hline Stream length (km) & 152.6 & 200 & 175 & 323 & 57.8 \\
\hline Drainage area $\left(\mathrm{km}^{2}\right)$ & 1955 & 7281 & 2139 & 18,648 & 1107 \\
\hline Drainage density $\left(\mathrm{km}^{-1}\right)$ & 0.08 & 0.03 & 0.08 & 0.02 & 0.05 \\
\hline
\end{tabular}

\section{Data and Methods}

\subsection{Datasets}

The Advanced Spaceborne Thermal Emission and the Reflection Radiometer (ASTER) Global Digital Elevation Model (GDEM) provided the elevation data for the Qaidam Basin with high resolution and accuracy. The spatial resolution of the GDEM is about $30 \mathrm{~m}$. Photos of the streams on the Qaidam Basin were collected during the fieldwork, providing evidence that a river once crossed the valley. The studied valleys in the Qaidam Basin were automatically extracted by ArcGIS 10.2 [21]. Consequently, we removed the misidentified valleys manually by comparing the visible light image in Google Earth with the valleys selected by ArcGIS. Our results include 184,024 segments of streams in the Qaidam Basin distributed around the edge of the Basin. We used the Martian valleys identified by Hynek [9] in this work. Then, we chose rivers in the northwestern Mangya area to compare with Martian valley networks. These valley networks were supplied by precipitation and ended in the arid Qaidam Basin, characterized by high evaporation rates and high UV. By using the Resample tool to reduce the resolution of the data in the Mangya area, we also compared Martian valley networks at the same spatial resolution (460 m).

Martian valley networks were generated with the Thermal Emission Imaging System (THEMIS) data on top of the Mars Orbiter Laser Altimeter (MOLA) shaped relief map [8,9]. The MOLA data show Mars' elevation with a spatial resolution of about $460 \mathrm{~m}$ and a vertical resolution of $30 \mathrm{~cm} /$ pixel. From the global Martian valley networks, we chose the three studied cases formed during different periods to compare with the terrestrial rivers.

\subsection{Geomorphology Parameters of Valley Network}

To characterize the geometry of the valley networks on Mars and Earth, previous work has typically used some key parameters, including drainage area, stream length, drainage density, branching angle, stream frequency and bifurcation ratio (Table 2), as climate indicators. And they have used these parameters to investigate the history of the evolution and environment on the Mars by comparing the valley networks between the Earth and Mars [12,22]. 
Table 2. Formula and definition of morphometric parameters of a drainage basin.

\begin{tabular}{|c|c|c|}
\hline Parameters & Formula/Definition & Potential Indications \\
\hline Drainage area $(\mathrm{A})$ & Area of the drainage basin & Discharge and stream environment \\
\hline Stream order $(\mathrm{u})$ & Stream hierarchical order & $\begin{array}{l}\text { Scale-dependent, larger map scale with } \\
\text { more orders of stream revealed }\end{array}$ \\
\hline Stream length $(\mathrm{L})$ & $\begin{array}{l}\text { Length of the stream from the source in the } \\
\text { watershed to the outlet }\end{array}$ & $\begin{array}{l}\text { Low slope with a shorter length than a } \\
\text { high slope }\end{array}$ \\
\hline Stream frequency $\left(\mathrm{F}_{\mathrm{S}}\right)$ & $\begin{array}{l}\mathrm{F}_{\mathrm{S}}=\mathrm{N} / \mathrm{A}, \mathrm{N} \text { is the total number of all the stream } \\
\text { segments and } \mathrm{A} \text { is the area of the drainage basin }\end{array}$ & $\begin{array}{l}\text { The influence of rainfall and the } \\
\text { physiography of the region }\end{array}$ \\
\hline Stream slope & $\begin{array}{l}\mathrm{S}=\nabla \mathrm{H} / \mathrm{D}, \mathrm{H} \text { is the elevation of the end and the } \\
\text { head/source of the stream, } \mathrm{D} \text { is the distance } \\
\text { between the end and the head/source }\end{array}$ & $\begin{array}{l}\text { Flow velocity and stream power, the } \\
\text { steeper the slope, the faster the velocity } \\
\text { of flow }\end{array}$ \\
\hline Branching angle ( $\Psi)$ & $\begin{array}{l}\text { Angle of the two flows collection to a sin gle stream, } \\
\Psi=\psi_{1}+\psi_{2}, \psi_{1} \text { and } \psi_{2} \text { are the two contributions }\end{array}$ & $\begin{array}{l}\text { Narrower in an arid area than in a } \\
\text { humid area }\end{array}$ \\
\hline Drainage density $(\mathrm{Dd})$ & $\begin{array}{l}\mathrm{Dd}=\mathrm{L}_{\text {total }} / \mathrm{A}, \mathrm{L}_{\text {total }} \text { means the total length of the } \\
\text { integral stream and } \mathrm{A} \text { is the drainage area of the } \\
\text { basin }\end{array}$ & $\begin{array}{l}\text { Soil permeability and underlying rock } \\
\text { type affect the runoff in a watershed }\end{array}$ \\
\hline Bifurcation ratio $(\mathrm{Rb})$ & $\begin{array}{l}\mathrm{Rb}=\mathrm{N}_{\mathrm{u}} / \mathrm{N}_{\mathrm{u}+1}, \mathrm{Nu} \text { is the stream number of the } \\
\text { stream order, } \mathrm{u} \text {, and } \mathrm{Nu}+1 \text { is the stream number of } \\
\text { the next higher order, } \mathrm{u}+1\end{array}$ & Highly stable for different environments \\
\hline $\begin{array}{l}\text { Normalized concavity } \\
\text { index }(\mathrm{NCI})\end{array}$ & $\begin{array}{l}\mathrm{NCI}=\text { median }\left(\Delta \mathrm{E}_{\mathrm{L}} / \Delta \mathrm{E}\right), \Delta \mathrm{E}_{\mathrm{L}} \text { is the elevation } \\
\text { difference of the streamed line to straight line } \\
\text { and } \Delta \mathrm{E} \text { is the elevation difference of upstream to } \\
\text { downstream }\end{array}$ & $\begin{array}{l}\text { The shape of a stream is controlled by the } \\
\text { climate }\end{array}$ \\
\hline
\end{tabular}

The drainage area is the entire area connecting to the stream or stream system, which is discharged through a single outlet in the stream flow [23] and is influenced by both the discharging and the stream environment. The different fields characterized by changes in the climate, such as precipitation, are manifest in the range of shapes of valley networks.

The stream length is indicative of the chronological developments of the stream segments and surface runoff characteristics [24]. Streams with relatively shorter lengths are representative of areas with steep slopes and fine textures, whereas longer lengths of a stream are generally indicative of low gradients [25]. The mean stream length is calculated by dividing the total stream length of a given order by the number of streams in that order. It is a characteristic property related to drainage and its associated surfaces [25].

The stream frequency is the ratio of the number of all streams in the basin to the drainage area [26]: it indicates the development stage of the evolution of the landscape and is dependent on the rainfall and the physiography of the region [24]. This index is influenced by various parameters such as permeability, infiltration capacity and relief of the subwatershed. And the parameter shows a positive correlation with the drainage density [27].

Meanwhile, the drainage density is defined as the ratio of total stream length in a given basin to the total drainage area [26]. It is related to stream channels and the degree of drainage development, determining the time of travel by water and providing a numerical measurement of landscape dissection and runoff potential.

The bifurcation ratio, defined as the ratio of the number of stream segments of a given order to the number of segments of the next-highest order, is an index of relief and dissections [26]. It is highly stable and influenced by the different environments at a small range, except where significant geologic controls dominate [25].

The relationship between the climate and these parameters has many uncertainties that may influence the results. The parameters are always affected by two or more factors, such as sedimentation, topography, and the geological history. Additionally, we expect that the evolutionary history and developmentary stages of streams on different planets to be different, although they also share some similarities. For example, a comparative study between rivers in the Tarim Basin and Evros Vallis on Mars shows a general suggesting that the estimated paleo-discharge increased gradually from upstream to downstream, 
with the dendritic tributaries and confluences effectively adding more discharge to the mainstream [12].

The branching angle (BA), defined as the angle of the two flows collected into a single stream, is influenced by the environment. On Earth, valley networks in arid landscapes have more surface runoff branch at narrower angles, while in humid environments with more groundwater flow branching angles are much wider [7], up to nearly $72^{\circ}$ in humid fields [10]. Although the BA is also affected by multiple factors, a strong correlation between the BA and climatic aridity is observed worldwide [7]. Consequently, we use this parameter as a climate indicator in this work.

Seybold $[7,10]$ obtained the BA $(\varphi)$ based on the geometry of the valley network, using Equation (1) (Appendix A Figure A1a):

$$
\varphi=\varphi_{1}+\varphi_{2}
$$

where $\varphi_{\mathrm{i}} \equiv 0$ if $\cos \varphi_{\mathrm{i}}>1,(\mathrm{i}=1,2)[28]$ :

$$
\cos \varphi_{1}=\left(\frac{\mathrm{Q}_{1}+\mathrm{Q}_{2}}{\mathrm{Q}_{1}}\right)^{\mathrm{n}}, \cos \varphi_{2}=\left(\frac{\mathrm{Q}_{1}+\mathrm{Q}_{2}}{\mathrm{Q}_{2}}\right)^{\mathrm{n}}
$$

where $\mathrm{S}=\mathrm{kQ}^{\mathrm{n}}, \mathrm{S}$ is the slope, and $\mathrm{Q}$ is discharge of the upstream tributaries; the calculations of $\mathrm{k}, \mathrm{n}$ can be found in $[28,29]$.

Later, Cang [29] set up a different approach by using the valley network's topological information to calculate the BA $(\varphi)$ (Appendix A Figure A1b):

$$
\varphi=\frac{\mathrm{S} \times 360^{\circ}}{\mathrm{A}}
$$

where $\mathrm{A}$ is the area of the buffer circle and $\mathrm{S}$ is the occupied area of the BA.

By applying this method, the absence of information on the discharge of the Martian valley network is addressed. Similarly, we used Python code to automatically extract the

\begin{tabular}{|c|c|c|c|c|}
\hline Extract the VN & $\square$ & $\begin{array}{l}\text { Determine the } \\
\text { convergence } \\
\text { point }\end{array}$ & 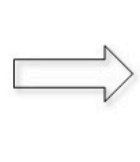 & $\begin{array}{l}\text { Determine the } \\
\text { upstream and } \\
\text { downstream }\end{array}$ \\
\hline
\end{tabular}
BA of Mars and of the Qaidam Basin (Figure 2a).

\begin{tabular}{|c|c|c|c|c|}
\hline $\begin{array}{l}\text { Calculate the } \\
\text { BA }(\alpha) \text { : } \\
\quad \alpha=\frac{A}{S} \times 360^{\circ}\end{array}$ & $\longrightarrow$ & $\begin{array}{l}\text { Calculate the } \\
\text { area of BA }(\mathrm{A}) \\
\text { and the area of } \\
\text { the circle }(\mathrm{S})\end{array}$ & 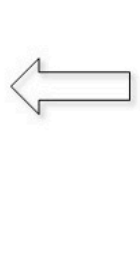 & $\begin{array}{l}\text { Set the } \\
\text { convergence } \\
\text { point as the } \\
\text { center to draw } \\
\text { a } 10 \mathrm{~m} \text { circle }\end{array}$ \\
\hline
\end{tabular}

a

Figure 2. Cont. 


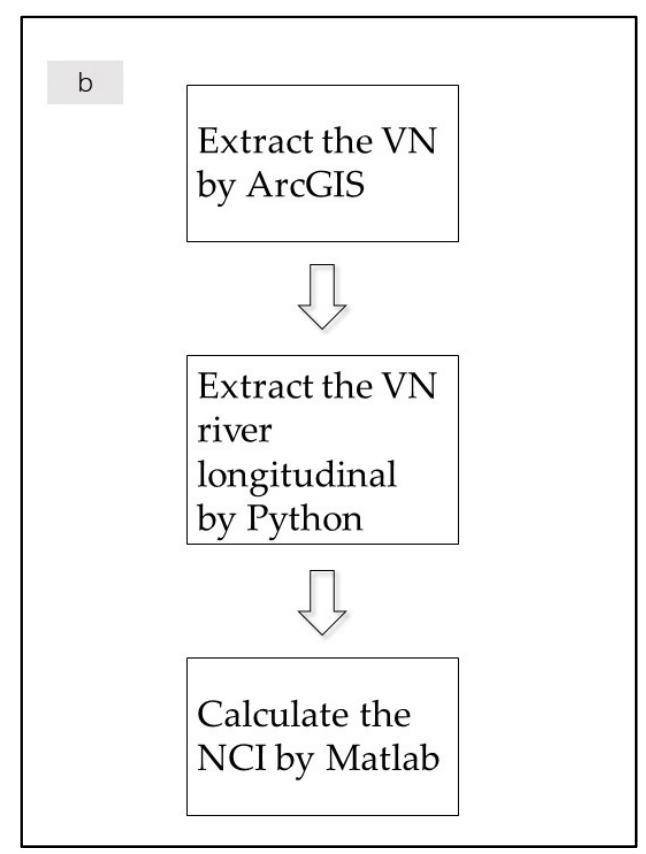

Figure 2. The diagram of the calculation procedures of the (a) branching angle (BA) and the (b) normalized concavity index (NCI) of the longitudinal profiles of the rivers. VN: valley network. BA: branching angle.

The estimated BA of streams in the Mangya area is the same as the results calculated with the two methods proposed by Seybold [7,10] and Cang [29], which is about 61 degrees.

Another important parameter that shows a close correlation with climatic aridity is the normalized concavity index (NCI), calculated with the longitudinal profiles (elevation versus distance downstream) of the rivers [11]. When the NCI is negative, the river is formed by increasing the discharge of the downstream and perennial flow conditions and the longitudinal profile of the stream concave up. If the NCI is equal to zero, the longitudinal profile is straight, implying the river developed in an infrequent flow regime, the median discharge of which would be stable along the channel for a long time. If the NCI is positive, the profile is convex, and the stream is developed in ephemeral or perennial conditions that are not controlled by the climate [11]. Using SRTM-DEM and MOLA data, we extracted the streams on Mars and the Qaidam Basin with ArcGIS hydrological analysis tools. Next, we extracted the main stream from the source to the end to obtain the river longitudinal profiles and the elevations of the riverbed. Finally, we can calculate the NCI with Equation (4) [11].

$$
\mathrm{NCI}=\operatorname{median}\left(\frac{\mathrm{E}_{\mathrm{L}}-\mathrm{Y}_{\mathrm{L}}}{\mathrm{E}_{0}-\mathrm{E}_{\mathrm{n}}}\right)
$$

where $\mathrm{L}$ represents the distance from the origin to the downstream, $\mathrm{E}_{\mathrm{L}}$ is the elevation of the longitudinal profile, $Y_{L}$ is the elevation of the straight line between the origin and the end of the river, $\mathrm{E}_{0}$ shows the original elevation, and $\mathrm{E}_{\mathrm{n}}$ represents the elevation of the end of the river. The procedures of extracting $\mathrm{NCI}$ are shown in Figure $2 \mathrm{~b}$.

\subsection{Martian Valley Network}

The primary global map of Martian valley networks based on Viking data was produced by Carr [24]. The highest stream order in the map is four and the number of the valleys is 10,748 . However, because of the non-uniform quality and spatial resolution of the Viking data, the capability to distinguish the small valley is limited, and the features vary greatly depending on the lighting geometries. With THEMIS and MOLA data, a fluvial system of higher stream orders was extracted in many local regions. As shown in the higher resolution map provided by Hynek [9], the recognized stream number was increased to 82,217 and the highest stream order is up to seven. The total length of the global valley 
networks on Mars has increased from 342,384 km to 781, $393 \mathrm{~km}$, with details of the valley networks shown in the new map (Figure 3). The valley networks are distributed along the longitude on Mars. With altitude, the valleys spread at the low-middle areas between around $60^{\circ} \mathrm{S}-60^{\circ} \mathrm{N}$.

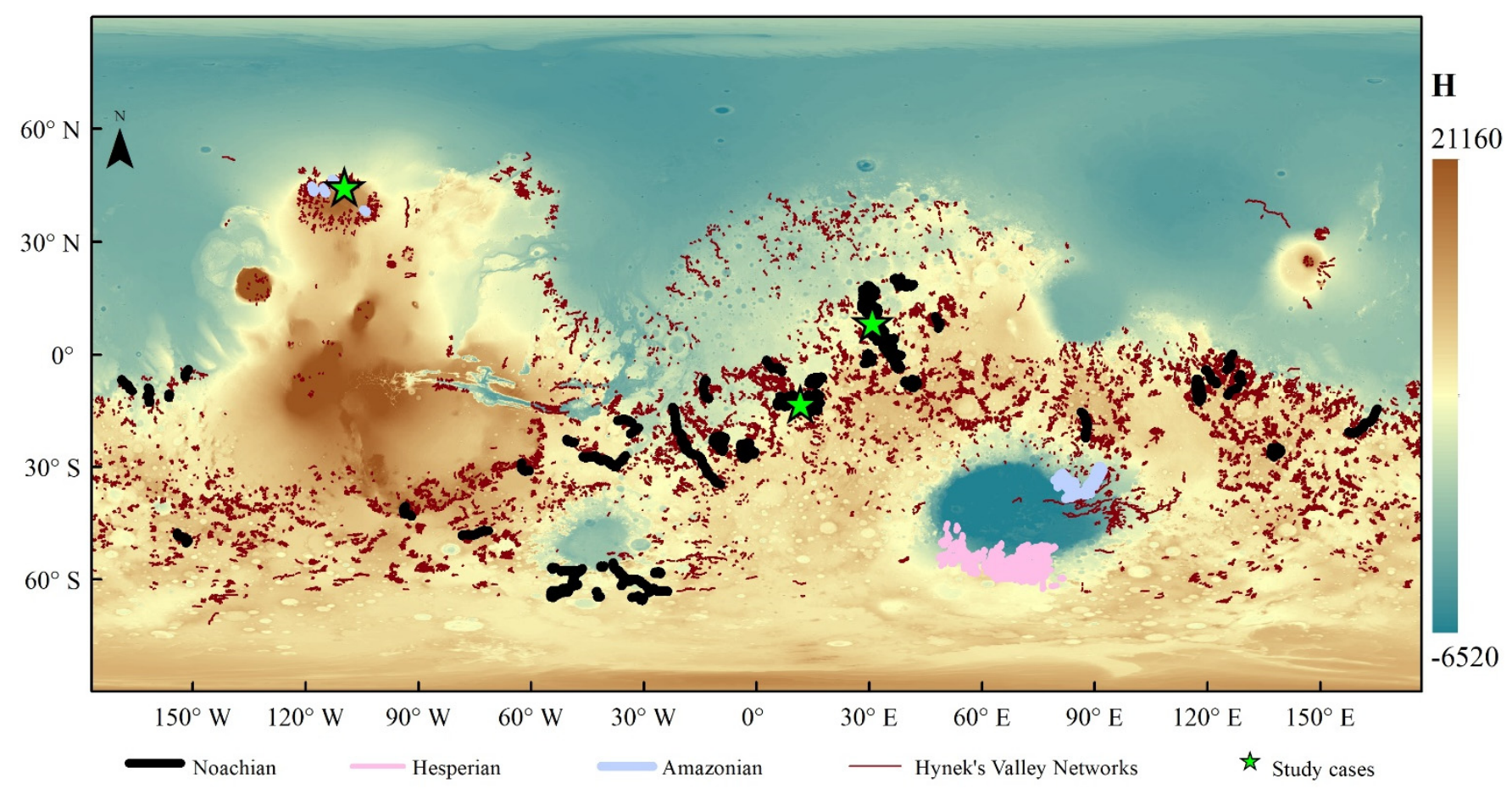

Figure 3. The studied valley networks on Mars. The blue, pink, and white colors represent the valley networks formed during the Amazonian, Hesperian, and Noachian, respectively. The crimson lines denote the global valley network system on Mars recognized by Hynek 2010 and Alemanon 2018. The base map is MOLA DEM.

Interpreting the global valley network based on the local geology [8] or using crater counting methods [9] represent the most common approaches for estimating the age of valley networks on Mars. With these two methods, previous studies concluded that most valley networks seem to be formed in the late Noachian to the early Hesperian, around 3.8-3.6 Ga. Around $91 \%$ of the valley networks were formed in the Noachian, with a dendritic shape, while only $6 \%$ and $3 \%$ of them were formed in the Hesperian or Amazonian, respectively [9].

Most Martian valley networks are thought to be formed by long-lived surface runoff from precipitation in the Noachian, Hesperian, and early Amazonian [1,8,9,30]. Groundwater processes or transient steam atmospheres played, at most, a minor role in forming these networks $[7,9]$. Fluvial runoff erosion would require very different climatic conditions than those that we observe on Mars. Frequent precipitation and an active hydrological cycle are necessary to support a significant amount of overland flow, with temperatures at least episodically rising to allow liquid water to exist, also requiring a thicker $\mathrm{CO}_{2}$ atmosphere. However, this fails to explain how the climate varied in the past. According to the latest research, the formation timescales of the fluvial system from $1 \times 104 \mathrm{yr}$ to $2 \times 108 \mathrm{yr}$ developed in a typical humid or sub-humid condition with an intermittent flow of $5 \%$, and the formation timescales from $5 \times 104 \mathrm{yr}$ to $8 \times 108 \mathrm{yr}$ are more likely have developed in a semiarid or arid environment [31]. However, the past paleoclimate of Mars and the formation mechanisms of the valley networks are still open to debate. Alternatively, some researcher suggests that during the Noachian Mars was still cold and icy. The formation of the valley networks was a result of changing local climate by igneous activity [32,33].

Valleys formed in the Noachian are absent around volcanos, such as Tharsis, and the basins, e.g., the Hellas Basin. This is due to many different factors. For instance, the 
early volcanic activity and the resurfacing may have caused uncertainties in the correct determination of their ages. Around the volcanos, the valleys were probably formed by lava tubes with groundwater sapping. Resurfacing has been observed with the features of valley networks [8]. The youngest valleys on the planet are confined to volcanic constructs and are most likely to have a hydrothermal origin $[8,9]$, such as the volcanos found in Alba Patera.

In this work, three cases of a Martian valley formed in different geologic periods were selected for detailed comparisons with those in the Qaidam Basin. In addition, we calculated the BAs of the global valley networks ( 10022 valley networks) on Mars, all the streams in the Mangya area, and the NCI of 71 selected valley networks for the analysis of the climate of different Martian periods.

\section{Results}

\subsection{Geomorphology Comparison}

By extracting the streams within the Qaidam Basin, it is clear that these are distributed along the edge of the Basin (Figure 1). The streams developed along the slopes of the mountains, which provided the water source. With decreasing snowmelt and the runoff changing to groundwater, the flow volume reduced and disappeared below the floor of the Basin. The different water sources of the Basin dictate the various hydrological characteristics from the northwest to the southeast. The streams on the northwest, the Mangya area, have low stream density, short stream length (nearly end after flowing out of the mountain), and a small drainage area, with low precipitation and high evaporation rates. For the southeast area, groundwater is the main water source. The drainage area and stream length are larger than those in the northwest. Many streams accumulate to form lakes such as the Dabuxun lake, the Huobuxun lake, and the Dulan lake in the southeast area. Table 1 shows the hydrological details of the different streams on the Qaidam Basin. The water sources do not influence the drainage density.

The low precipitation results in an insufficient water supply in the center of the Basin. The streams in the center are absent and they usually end in dry salt lakes, such as Mangya and Yi Liping. We chose the streams of the Mangya area, sitting in the northwest of the Qaidam Basin, to show the details of the valley networks in the Qaidam Basin. The streams formed the dendritic system with many tributaries. The origin in the mountain provides little melted ice water for the streamflow. The stream order near the origin is lower than that of the farther side. With a higher stream order, the flow volume decreases and the streams become wider and shallower.

The valley networks on Mars formed in different periods display characteristic morphological features. Figure 4 shows three samples of the valley networks on Mars for each period. The positions of the study cases on the global map are marked by green stars in Figure 3. The oldest valley formed in the Noachian, Evros Vallis, is the most complex, with the highest stream order dendritic system. Naktong Vallis represents the early Hesperian valley network, showing a relatively simple pattern compared to the Noachian valley. The highest stream order is five, with a less dendritic shape than the Noachian, whereas the Amazonian valley network in the Alba Patera is different from the previous two. Most of the Amazonian valley network has small drainage areas, short stream lengths, and a few tributaries. The branching angles of the valley networks formed in different periods are also varied. From Figure 4, we can observe that the branching angle of the Amazonian valley is smaller than that of the others. 

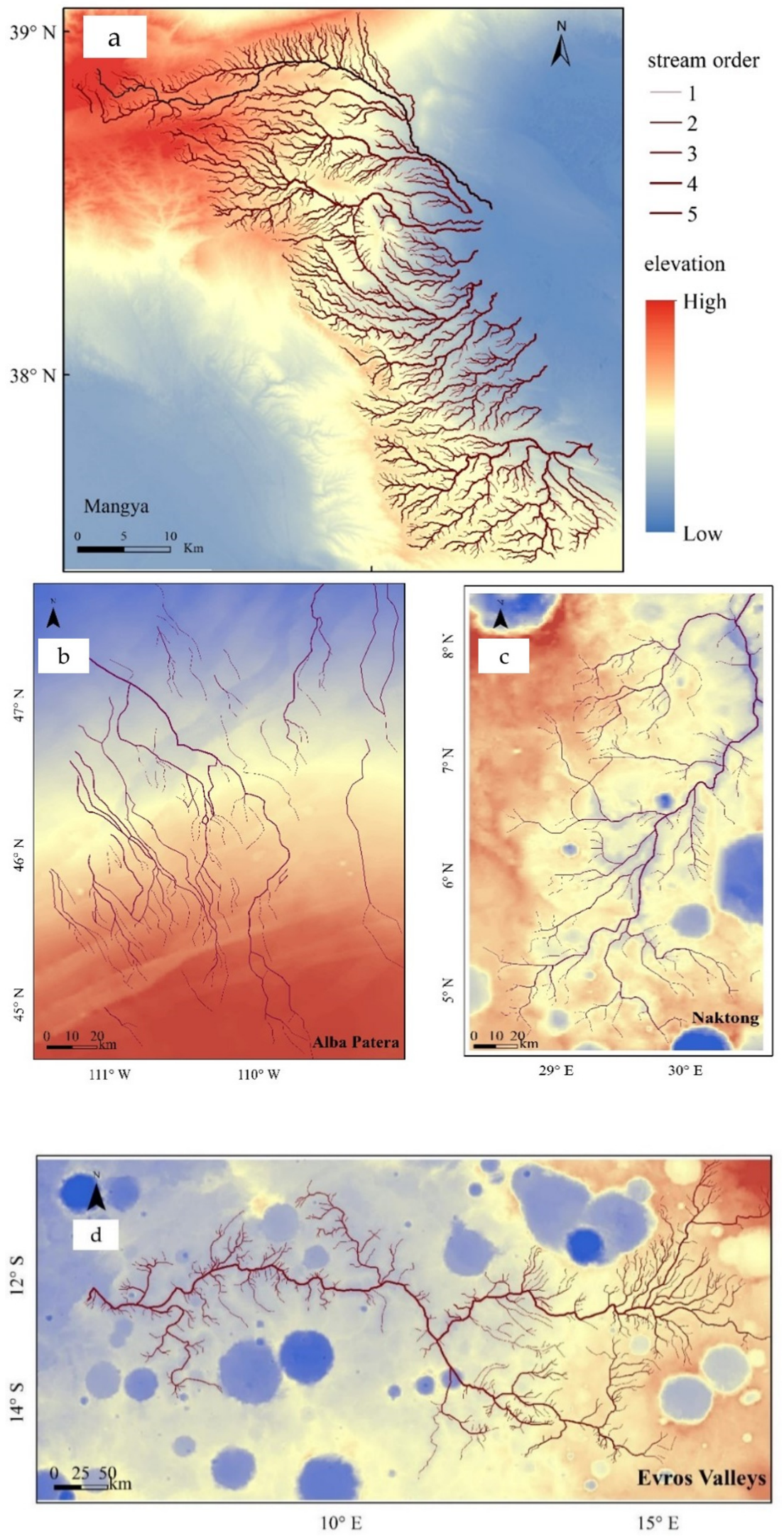

Figure 4. The extracted valley networks in the Qaidam Basin and on Mars. (a) The Manya river is in the Qaidam Basin. (b) The Alba Patera valley is the Amazonian valley network on Mars. (c) Naktong Vallis is the Hesperian valley network. (d) Evros Vallis is the Noachian valley network. The age of a valley network is determined by crater counting [8,9]. The base map is MOLA DEM data. 


\subsection{Morphometric Parameters}

For the analogue study, we extracted the morphologic parameters of valley networks on Mars and the Qaidam Basin as listed in Table 3. Table 4 shows that the extracted parameters of Evros Vallis in this work are compared with other studies to demonstrate the feasibility of our measurement approaches. Comparisons of the parameters in Table 3 show that, in general, the scale of the valley networks on Mars is several times larger than that in the Qaidam Basin, in terms of drainage area and stream length. However, the dimensionless parameters, such as fractal dimension, stream order, and NCI, show a similarity between the stream in the Mangya area and the Naktong or Evros Valley on Mars. The fractal dimension represents the stage of the erosion process of the valley and the landscape: this value is equal to 1.0-1.6 when the stream is young, and with maturity it usually rises to a value between 1.6 and 1.89. A fractal dimension value of over 1.89 but less than 2.0 is the oldest stage [22]. Our results show that Naktong Vallis, formed in the Hesperian (1.55), is younger than Evros Vallis, formed in the Noachian (1.63), and the stream in Mangya, in the Qaidam Basin (1.7).

Table 3. The morphometric parameters of valley networks on Mars and the Qaidam Basin. Mangya-high and Mangya-low represent the parameters extracted from elevation data with a horizontal resolution of $30 \mathrm{~m}$ and $463 \mathrm{~m}$, respectively.

\begin{tabular}{|c|c|c|c|c|c|}
\hline Parameters & Evros Vallis & $\begin{array}{l}\text { Naktong and } \\
\text { Others }\end{array}$ & Alba Patera & Mangya-High & Mangya-Low \\
\hline Stream length $(\mathrm{km})$ & 9050 & 2563 & 2708 & 1526 & 486 \\
\hline Area $\left(\mathrm{km}^{2}\right)$ & 149,700 & 22,200 & 35,473 & 1955 & 1332 \\
\hline Stream number & 1063 & 327 & 216 & 914 & 234 \\
\hline Stream frequency & 0.0071 & 0.0147 & 0.0061 & 0.4675 & 0.1757 \\
\hline Drainage density $\left(\mathrm{km}^{-1}\right)$ & 0.0605 & 0.1155 & 0.0763 & 0.7806 & 0.3649 \\
\hline Fractal dimension & 1.63 & 1.55 & 1.36 & 1.7 & 2.0 \\
\hline Stream order & 6 & 6 & 4 & 5 & 3 \\
\hline Slope $(\mathrm{m} / \mathrm{km})$ & 3.7 & 2.3 & 18.2 & 33.3 & 27.5 \\
\hline Branching angle $\left(^{\circ}\right)$ & $56-74$ & $50-66$ & $39-56$ & $39-57$ & $39-57$ \\
\hline $\mathrm{NCI}$ & -0.74 & -0.62 & -0.47 & -0.62 & -0.56 \\
\hline
\end{tabular}

Table 4. Comparison of extracted results of Evros Vallis.

\begin{tabular}{cccccc}
\hline Studies & $\begin{array}{c}\text { Stream Length } \\
\mathbf{( k m )}\end{array}$ & Area $\left.\mathbf{( k m}^{\mathbf{2}}\right)$ & $\begin{array}{c}\text { Drainage } \\
\text { Density (km }\end{array}$ & Stream Order & Stream Number \\
\hline Hoke and Hynek, 2009 [2] & 9050 & 149,700 & 0.06 & 5 & - \\
Gou Sheng, 2018 [22] & 5040 & 105,906 & 0.05 & 5 & 163 \\
This study & 9050 & 149,700 & 0.06 & 5 & 1063 \\
\hline
\end{tabular}

As shown in Table 3, the reduced resolution of the DEMs has a limited effect on the dimensionless parameters of both the NCI and the BA. However, most of the tributaries in the Mangya area cannot be extracted with coarse resolution data, resulting in large errors of dimensional parameters such as stream length and number.

The scales of the Martian valleys are much larger than those on Earth, as shown in Table 3 and other related works [12,22] For example, the drainage area of the Martian valley is tens or even hundreds of times larger than Mangya's. Hence, the tributaries of the Martian valley are still recognizable even with relatively low-resolution MOLA data, while the counterparts on Earth, especially those developed in extremely arid environments, could lose detailed geomorphological features due to the spatial limitation of the data.

Figure 5 shows the longitudinal profiles of streams on Mars and the Qaidam Basin. For those formed in the Noachian and Hesperian, the profiles are concave up closely to the origin of the stream, and change to straight from the middle up to the end. The profile of the Amazonian valley starts as convex before then turning straight. When compared with similar studies, in terms of geomorphologic parameters, the streams on the Qaidam Basin 
are similar to Evros Vallis and Naktong Vallis, based on the observations of the branching with many tributaries as well as the high maturity and concave-up shape of the longitudinal profiles of the main stream. Considering the two parameters (NCI/longitudinal profile and BA) closely related to the climate, the Hesperian valley network on Mars is more similar to the stream on the Qaidam Basin.
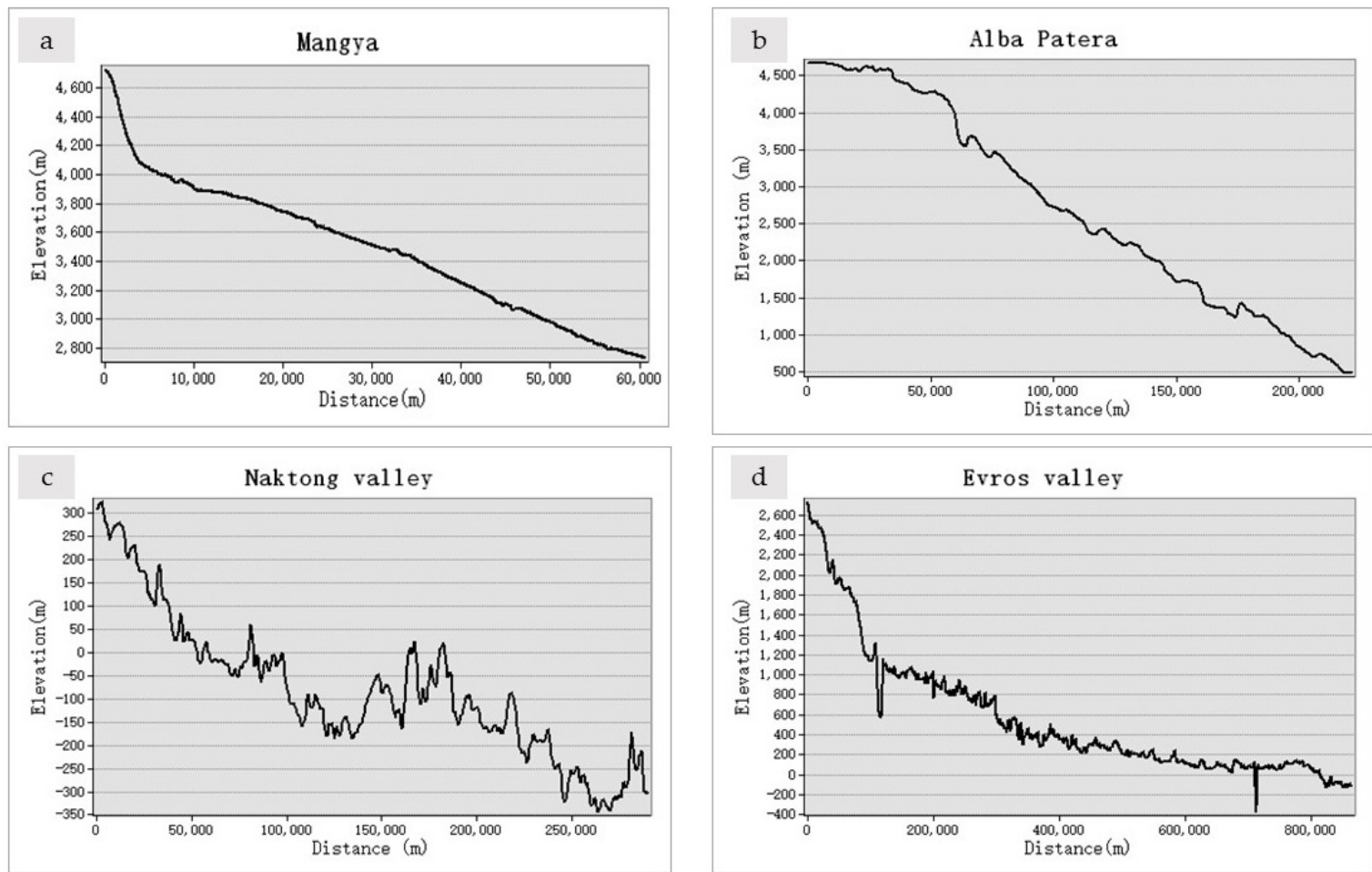

Figure 5. The river longitudinal profiles of the representative streams on Mars and the Qaidam Basin. (a) is the longitudinal profile of the river on the Qaidam Basin. (b-d) represents the Amazonian, Hesperian, and Noachian valley networks on Mars, respectively.

\subsection{Statistical Study of the BA and the NCI}

Figure 6 shows the statistical results of the distribution of the BAs of the valley networks formed in different periods on Mars. We can observe that the distribution peak of the branching angle in the Amazonian is near $18^{\circ}-36^{\circ}$, smaller than the peak values of the other two periods. The highest proportion of the tributary of the Noachian and Hesperian valley networks branch to a wider angle of nearly $36^{\circ}-54^{\circ}$. It suggests that the late Noachian to early Hesperian was more humid than the Amazonian. This result is consistent with other studies [23]. The BA of all the streams in the Mangya area in the Qaidam Basin is $36^{\circ}-54^{\circ}$, which drops in the range of the peak of the valley networks in the Noachian and Hesperian. This is concurrent with the conclusion based on geomorphologic comparisons.

Figure 7 shows the distribution of the NCI of the 71 selected valley networks on Mars. Different colors indicate different formation periods. According to the relationship between streams and lakes, we divided the Noachian streams into two groups to extract longitudinal profiles and calculate the NCIs. The first group represents isolated inlet valleys with the root mean square (RMS) of the concavity index larger than 0.1. The other is a network-fed valley and shows the RMS of the concavity index to be smaller than 0.1 [34-37]. Nevertheless, the longitudinal profiles of these two groups show a concave-up shape. 


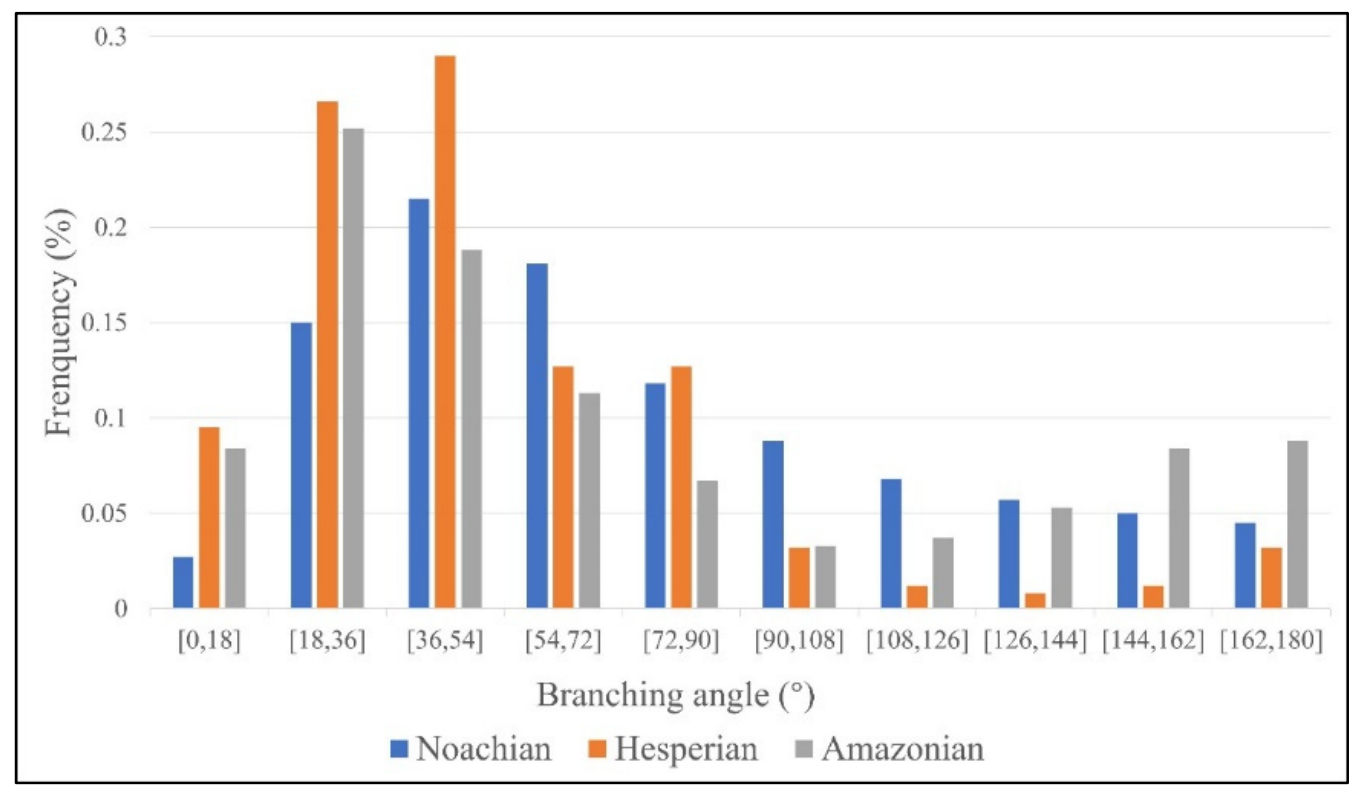

Figure 6. The distribution of branching angles of the valley networks formed in different periods on Mars.

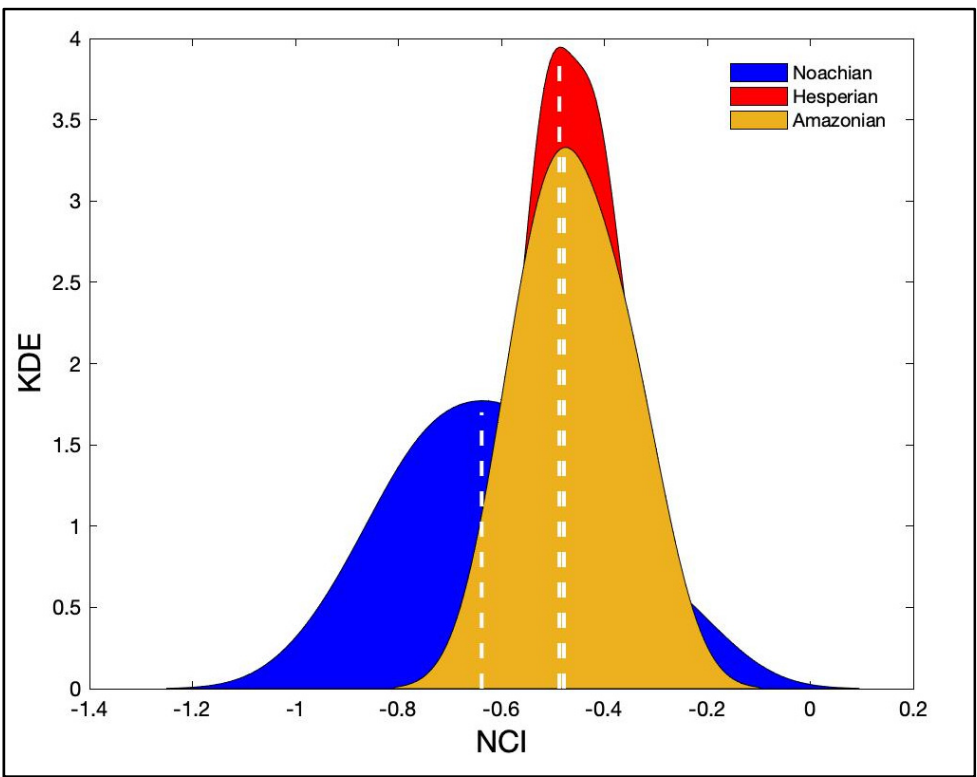

Figure 7. The distribution of the normalized concavity index of the valley networks on Mars. The white line is the median value of the index. Kernel density estimation (KDE) is a nonparametric representation of the probability density function.

Figure 7 suggests that the NCI of the valley networks formed in the Amazonian is closer to zero than that of Noachian valley networks and Hesperian valley networks, while the NCI of Noachian valley networks is the most negative among these three epochs. This indicates the environment in the Amazonian was more arid than the previous two, and that the Noachian valley networks had more abundant discharge and perennial flows. The increase in the NCIs from the Noachian to Amazonian provides evidence of the climate transition to more arid conditions on Mars.

\section{Discussion}

Based on our results, the stream length and drainage area of the three study cases on Mars are ten times larger than those in the Qaidam Basin, which agrees with the 
observations of other researchers [38]. The comparison of valley networks' parameters between Mars and Earth shows that for dimensional parameters, such as drainage area and stream length, Martian valley networks are usually tens of times larger than its terrestrial counterpart. However, the dimensionless parameters are relatively stable, and morphometrical features of the streams on Earth are similar to those of valley networks on Mars. The drainage density in the volcanic unit is $0.3-0.5 \mathrm{~km}^{-1}$, which is larger than that in the volcanic plain (close to 0) [39]. In terrains, the range of the drainage density varies from 1 to $100 \mathrm{~km}^{-1}$, where the drainage density is influenced by the precipitation rate and the subsequent redistribution [40]. The soil permeability and the underlying rock type affect the runoff in a watershed, but the environment and climatic conditions are in control of the drainage density. The extracted parameters of the three study cases show that the drainage density of the Martian valley networks in the Noachian, Hesperian, and Amazonian is 0.06, 0.12 , and 0.08 , respectively. The drainage density of the Qaidam Basin is about 0.08 , far less than the normal terrestrial value, indicating that the extremely arid climate condition obstructs the development of the stream.

The valley networks formed by melted ice, precipitation, groundwater sapping and subglacial have different shapes of the tributaries. The climate is the first-order control factor to influence the geometry of the valley networks. In a humid landscape, the branching angle is wider and intricate. The narrow-angle shape in the arid landscape is supplied by precipitation [7]. The climatic factor is also a controlling factor of the shape of the longitudinal profile, which varies in arid and humid areas. Analysis using the Kernel density estimation (KED) of the NCI and the Köppen-Geiger climate zones, which are classified by precipitation and temperature thresholds [41], shows that the development of the longitudinal profile does not change significantly over time. In a humid environment, the profile of the stream is concave up with a negative normalized concavity index. In an arid landscape, the NCI is nearly zero and the stream is straighter [11]. According to a study on the concavity and the relationship of the concavity with lakes on Mars, it is concluded that the formation of valley networks is under the control of sustained fluvial runoff [35]. The Martian valley networks formed in different geologic periods have distinctive morphological characteristics, as shown in Figure 4. The distributions of the BA and the NCI in different Martian epochs, both of which are climatic indicators, also have different peaks (Figures 6 and 7). This suggests that the climate on Mars experienced a change to more arid conditions.

\section{Conclusions}

The geomorphologic characteristics of valley networks can provide constraints to the climate of Mars in the past, although their relationships are still unclear. Analogy studies comparing rivers on Earth, with known water supplies and formation environments, with those on Mars can shed light on this matter. Through the comparative study of the valley networks on Mars and the Qaidam Basin, we have found that:

(1) In terms of morphology, the river network in the Mangya area of the Qaidam Basin, which is developed in an arid environment and supplied by low precipitation, is similar to the Hesperian valley network on Mars. The supply of the valley network of Naktong Vallis might be precipitation [42], the same as the streams in Mangya.

(2) Through the statistical study of the BA over 10,000 valley networks on Mars, the results show a correlation with climate in river databases all over the world. The BA in the Amazonian was smaller than those in the Noachian and Hesperian. This suggests that the environment became more arid during the Amazonian. The BA of streams in Mangya is in the range of peaks of the distributions in the Noachian and Hesperian.

(3) The NCI is another essential parameter that is proved to be the first order controlled by the climate. The results of this study show that the NCI (Noachian) $<\mathrm{NCI}$ (Hesperian) $<\mathrm{NCI}$ (Amazonian) < 0. It indicates that the climate on Mars may have changed from relatively wet to arid from the Noachian to the Amazonian. The NCI of streams in the Mangya area is close to the selected study case formed in the Hesperian. 
Author Contributions: Conceptualization, L.C. and Y.X.; methodology, L.C. and B.L.; software, L.C. and B.L.; validation, L.C. and Y.X.; formal analysis, L.C. and Y.X.; investigation, L.C. and Y.X.; writing—original draft preparation, L.C.; writing—review and editing, L.C. and Y.X.; visualization, L.C. and Y.X.; supervision, Y.X.; project administration, Y.X.; funding acquisition, Y.X. All authors have read and agreed to the published version of the manuscript.

Funding: This research was funded by the Pre-research Project on Civil Aerospace Technologies of CNSA (D020101), the Science and Technology Development Fund (FDCT) of Macau (grants 0042/2018/A2, 0089/2018/A3, and 0049/2020/A1).

Data Availability Statement: No new data were created or analyzed in this study. Data sharing does not apply to this article.

Acknowledgments: We thank the Roberto for proofreading the text.

Conflicts of Interest: The authors declare no conflict of interest.

\section{Appendix A}
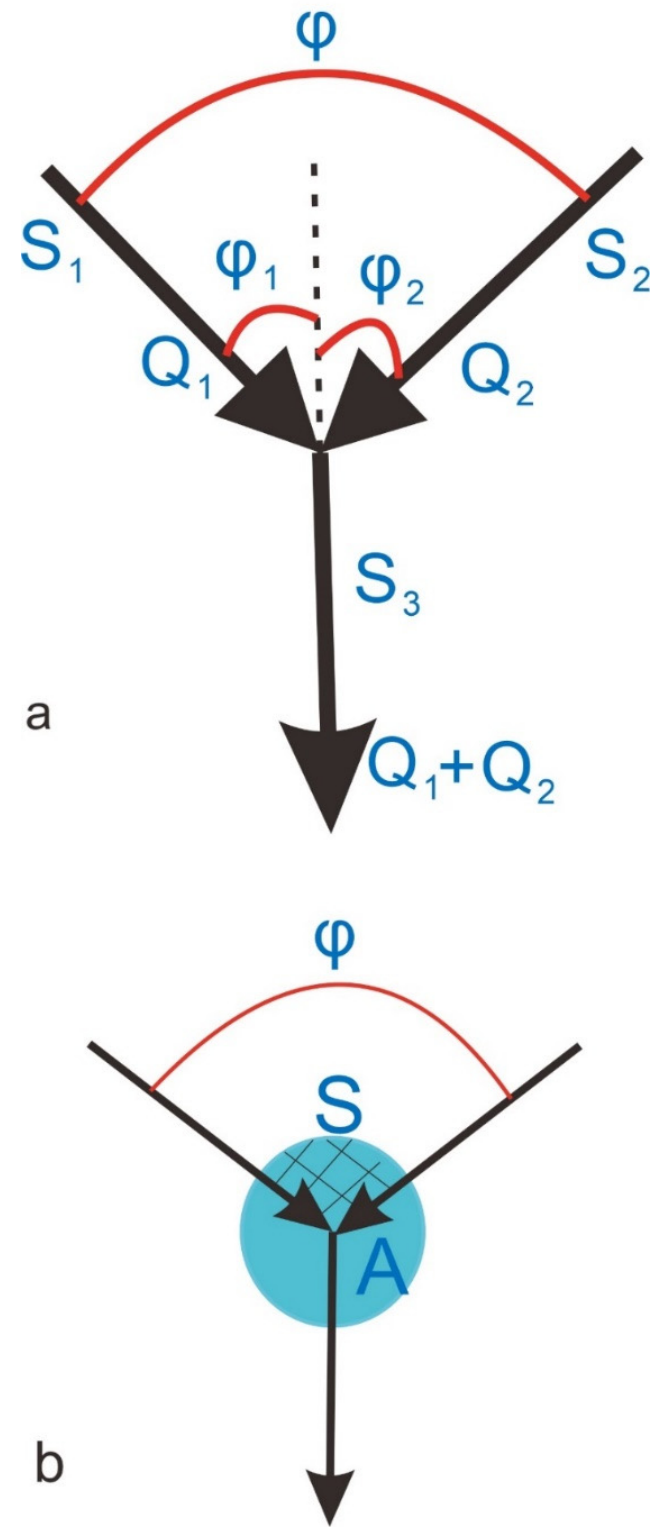

Figure A1. The definition of the different parameters to calculate the branching angle with (a) Seybold, 2017 and (b) Cang et al., 2019. 


\section{References}

1. Taylor, P.; Caprarelli, G.; Wang, B.Y. Wet Mars implications of revised scaling calculations for Evros Vallis. Aust. J. Earth Sci. 2012, 59, 37-41. [CrossRef]

2. Hoke, M.R.T.; Hynek, B.M. Roaming zones of precipitation on ancient Mars as recorded in valley networks. J. Geophys. Res. Planets 2009, 114, 2008JE003247. [CrossRef]

3. Pollack, J.B.; Kasting, J.F.; Richardson, S.M.; Poliakoff, K. The case for a wet, warm climate on early Mars. Icarus 1987, 71, $203-224$. [CrossRef]

4. Malin, M.C. Evidence for Recent Groundwater Seepage and Surface Runoff on Mars. Science 2000, 288, 2330-2335. [CrossRef]

5. Luo, W. Hypsometric analysis of Margaritifer Sinus and origin of valley networks. J. Geophys. Res. 2002, 107, 5071. [CrossRef]

6. Irwin, R.P.; Craddock, R.A.; Howard, A.D. Interior channels in Martian valley networks: Discharge and runoff production. Geol. Soc. Am. 2005, 33, 489-492. [CrossRef]

7. Seybold, H.J.; Kite, E.; Kirchner, J.W. Branching geometry of valley networks on Mars and Earth and its implications for early Martian climate Branching angle. Sci. Adv. 2018, 4, 1-6. [CrossRef] [PubMed]

8. Alemanno, G.; Orofino, V.; Mancarella, F. Global Map of Martian Fluvial Systems: Age and Total Eroded Volume Estimations. Earth Space Sci. 2018, 5, 560-577. [CrossRef]

9. Hynek, B.M.; Beach, M.; Hoke, M.R.T. Updated global map of Martian valley networks and implications for climate and hydrologic processes. J. Geophys. Res. 2010, 115, E09008. [CrossRef]

10. Seybold, H.; Rothman, D.H.; Kirchner, J.W. Climate 's watermark in the geometry of stream networks. Geophys. Res. Lett. 2017, 44, 2272-2280. [CrossRef]

11. Chen, S.A.; Michaelides, K.; Grieve, S.W.D.; Singer, M.B. Aridity is expressed in river topography globally. Nature 2019, 573, 573-577. [CrossRef]

12. Gou, S.; Yue, Z.; Di, K.; Xu, Y. Comparative study between rivers in Tarim Basin in northwest China and Evros Vallis on Mars. Icarus 2019, 328, 127-140. [CrossRef]

13. Jaumann, R. Interior channels in Martian valleys: Constraints on fluvial erosion by measurements of the Mars Express High Resolution Stereo Camera. Geophys. Res. Lett. 2005, 32, L16203. [CrossRef]

14. Ying, H.; Song, C.; Bao, J.; Feng, Y.; Hu, C. Paleoclimate change since the Middle Miocene in the northeastern Qaidam basin. Quaternany Sci. 2016, 36, 148-162. [CrossRef]

15. Jin, X.; Liu, J.; Wang, S.; Xia, W. Vegetation dynamics and their response to groundwater and climate variables in Qaidam Basin, China. Int. J. Remote Sens. 2016, 37, 710-728. [CrossRef]

16. Xiao, L.; Wang, J.; Dang, Y.; Cheng, Z.; Huang, T.; Zhao, J.; Xu, Y.; Huang, J.; Xiao, Z.; Komatsu, G. A new terrestrial analogue site for Mars research: The Qaidam Basin, Tibetan Plateau (NW China). Earth-Sci. Rev. 2017, 164, 84-101. [CrossRef]

17. Zhisheng, A.; Kutzbach, J.E.; Prell, W.L.; Porter, S.C. Evolution of Asian monsoons and phased uplift of the Himalaya-Tibetan plateau since Late Miocene times. Nature 2001, 411, 62-66. [CrossRef]

18. Wang, E.; Xu, F.Y.; Zhou, J.X.; Wan, J.; Burchfiel, B.C. Eastward migration of the Qaidam basin and its implications for Cenozoic evolution of the Altyn Tagh fault and associated river systems. Bull. Geol. Soc. Am. 2006, 118, 349-365. [CrossRef]

19. Hengshu, D.; Songgui, W. The study of the evolution of the Mesozoic and Cenozoic structures in the northeast margin of Caidam Basin. Earth Sci. J. China Univ. Geosci. 1991, 16, 533-539. [CrossRef]

20. Jiazhen, Z.; Enbao, L. Hydrological characteristics of streams in Qaidam basin. Acta Geogr. Sin. 1985, 40.

21. esri. Available online: https://www.esri.com/en-us/arcgis (accessed on 1 November 2021).

22. Gou, S.; Yue, Z.; Di, K.; Xu, Y. Quantitative comparison of morphometric and hydrological characteristics of valley networks between Evros Vallis on Mars and Kaidu River in Tarim Basin as terrestrial analog. Yaogan Xuebao/J. Remote Sens. 2018. [CrossRef]

23. Ray, K.; Linsley, J.; Max, A.K.; Joseph, L.H.P. Applied Hydrology; Tata McGraw-Hill Education: New York, NY, USA, 1949.

24. Magesh, N.S.; Jitheshlal, K.V.; Chandrasekar, N.; Jini, K.V. Geographical information system-based morphometric analysis of Bharathapuzha river basin, Kerala, India. Appl. Water Sci. 2013, 3, 467-477. [CrossRef]

25. Strahler, A.N. Quantitative analysis of watershed geomorphology. Eos, Trans. Am. Geophys. Union 1957, 38, 913-920. [CrossRef]

26. Horton, R.E. Erosional development of streams and their drainage basins; Hydrophysical approach to quantitative morphology. Bull. Geol. Soc. Am. 1945, 56, 275-370. [CrossRef]

27. Journal, I.; Geomatics, O.F. Watershed characteristics of Kundah sub basin using Remote Sensing and GIS techniques. Int. J. Geomatics Geosci. 2011, 2, 311.

28. Howard, A.D. Optimal Angles of Stream Junction: Geometric, Stability to Capture, and Minimum Power Criteria. Water Resour. Res. 1971, 7, 863-873. [CrossRef]

29. Roy, A.G. Optimal Angular Geometry Models of River Branching. Geogr. Anal. 1983, 15, 87-96. [CrossRef]

30. Carr, M.H. The Martian drainage system and the origin of valley networks and fretted channels. J. Geophys. Res. 1995, 100, 7479. [CrossRef]

31. Orofino, V.; Alemanno, G.; Di Achille, G.; Mancarella, F. Estimate of the water flow duration in large Martian fluvial systems. Planet. Space Sci. 2018, 163, 83-96. [CrossRef]

32. Turbet, M.; Forget, F.; Head, J.W.; Wordsworth, R. 3D modelling of the climatic impact of outflow channel formation events on early Mars. Icarus 2017, 288, 10-36. [CrossRef]

33. Halevy, I.; Iii, J.W.H. Episodic warming of early Mars by punctuated volcanism. Nat. Geosci. 2014, 7, 865-868. [CrossRef] 
34. Cang, X.; Luo, W. Noachian climatic conditions on Mars inferred from valley network junction angles. Earth Planet. Sci. Lett. 2019, 526, 115768. [CrossRef]

35. Grau Galofre, A.; Jellinek, A.M.; Osinski, G.R. Valley formation on early Mars by subglacial and fluvial erosion. Nat. Geosci. 2020, 13, 663-668. [CrossRef]

36. Grau Galofre, A.; Bahia, R.S.; Jellinek, A.M.; Whipple, K.X.; Gallo, R. Did Martian valley networks substantially modify the landscape? Earth Planet. Sci. Lett. 2020, 547, 116482. [CrossRef]

37. Goudge, T.A.; Fassett, C.I.; Head, J.W.; Mustard, J.F.; Aureli, K.L. Insights into surface runoff on early Mars from paleolake basin morphology and stratigraphy. Geology 2016, 44. [CrossRef]

38. Fassett, C.I.; Iii, J.W.H. Valley network-fed, open-basin lakes on Mars: Distribution and implications for Noachian surface and subsurface hydrology. Icarus 2008, 198, 37-56. [CrossRef]

39. Carr, M.H.; Chuang, F.C. Martian drainage densities. J. Geophys. Res. E Planets 1997, 102, 9145-9152. [CrossRef]

40. Abrahams, A.D.; Ponczynski, J.J. Drainage density in relation to precipitation intensity in the U.S.A. J. Hydrol. 1984, 75, 383-388. [CrossRef]

41. Peel, M.C.; Finlayson, B.L.; McMahon, T.A. Updated world map of the Köppen-Geiger climate classification. Hydrol. Earth Syst. Sci. 2007, 11, 1633-1644. [CrossRef]

42. Bouley, S.; Ansan, V.; Mangold, N.; Masson, P.; Neukum, G. Fluvial morphology of Naktong Vallis, Mars: A late activity with multiple processes. Planet. Space Sci. 2009, 57, 982-999. [CrossRef] 